\title{
Sumillera, Rocío G. (2019). Invention. The Language of English Renaissance Poetics. Legenda.
}

\author{
Daniel GutiÉrREz TrÁPAgA \\ Facultad de Filosofía y Letras \\ Universidad Nacional Autónoma de México | México \\ Contacto: danielgutierrez@filos.unam.mx
}

$\mathrm{L}$ a creatividad individual, la originalidad, la imaginación y la innovación no fueron los valores dominantes de la literatura, el arte y el saber sino hasta el Romanticismo. Por lo menos en la tradición occidental, dichas actividades se guiaban por conceptos como la mimesis o, más tarde, la imitatio, que prevaleció durante la Edad Media y el Renacimiento. La definición de estos y otros conceptos vinculados a la elaboración y el estudio de la literatura, dentro de los marcos de la retórica, la gramática y la dialéctica, no fue unívoca y sufrió transformaciones con los siglos. El libro de Rocío G. Sumillera Invention. The Language of English Renaissance Poetics se ubica en este complejo marco diacrónico y plurilingüe donde convergen diversos saberes y disciplinas. En particular, se centra en examinar la inventio, un concepto clave para comprender la literatura renacentista en inglés, vinculándolo tanto a los antecedentes clásicos como a los medievales, además de al quehacer del humanismo y otros autores de los siglos XVI y XVII. En ese sentido, el libro, desde su inicio, destaca por la aproximación comparativa, la vastedad de fuentes examinadas y su erudición. Sin perder su eje en la literatura inglesa, la obra resultará también de gran interés para los especialistas en el renacimiento francés, italiano y español.

Ya en la baja Edad Media, la escritura de la poesía, dentro del marco del aprendizaje retórico, estaba directamente ligada a la inventio, junto con la dispositio y la elocutio. Para el Renacimiento, el concepto de inventio, demuestra Sumillera, era ineludible en las discusiones y descripciones de la poesía y su elaboración, así como en las artes en general y en las ciencias. La premisa del libro de Sumillera parte de identificar el Renacimiento como un momento crucial en el auge y la transformación del concepto de inventio: "Thus, Renaissance invention, still imbued with rhetorical and dialectical nuances, helps to smooth the passage from the classical notion of poetry as imitation to the understanding that it is instead the product of the author's original thought and creative imagination" (2019: 2).

Para explorar el concepto de inventio en el Renacimiento inglés, el libro está dividido en cinco capítulos. El primero revisa las ideas retóricas, gramáticas y dialécticas de la Antigüedad y la Edad Media que daban sentido a la inventio, desde su origen en la teoría de los tópicos en la Retórica de Aristóteles. Sumillera muestra la influencia, tanto de las ideas del estagirita como de las de Cicerón, Quintiliano y Boecio, en la educación medieval retórica y dialéctica. Luego, analiza el concepto en la tradición de las ars grammatica y las artes poetriae, que permitió al concepto incorporarse a los lexicones de poética desde el siglo XII y XIII. 
El capítulo dos trata la inventio de los siglos $\mathrm{XV}$ al inicio del XVII en diversos autores europeos e ingleses, en particular los humanistas, en función de la discusión sobre Cicerón, desde la polémica entre Jorge de Trebisonda y Lorenzo Valla, y luego Rodolfo Agrícola, Juan Luis Vives y Pedro Ramo. Es precisamente en el siglo xv que la retórica se afianza como disciplina en Oxford y Cambridge y, en general, en la educación de la Inglaterra de los Tudor. Dicho contexto explica la aparición de los primeros tratados en inglés, comenzando con The art or crafte of rhetoryke (1535) de Leonard Cox, al que le siguieron obras de Richard Sherry, Angel Day y Thomas Wilson, entre otros. Sumillera plantea la coexistencia de dos líneas que presentan de manera distinta la idea de encontrar argumentos, una con buscar ideas ya existentes y la otra estableciendo un vínculo con la construcción de ideas por medio de la fantasía o la imaginación. La poesía, aún vista como una forma de elocuencia retórica y con influencia neoplatónica, incorporó en el siglo XVI a la Poética de Aristóteles como parte de su teoría; sin embargo, los poetas ingleses parecen haber tenido poco acceso al texto y a otras discusiones italianas o francesas en torno a la inventio en este contexto. En el caso inglés, domina claramente la retórica como clave poética.

En el capítulo tres, Sumillera revisa la relación entre la imitatio y la inventio, dentro del marco de la retórica, conceptos cuyo estudio conjunto es necesario. Nuevamente, la imitatio se remonta a uno de los ejercicios centrales de la retórica en la Antigüedad, vinculado a la traducción y, principalmente, a la transmisión de modelos para superarlos. Dicha idea permaneció durante la Edad Media y el Renacimiento, aunque no estuvo exenta de polémica en los círculos humanistas: algunos consideraban a Cicerón como el máximo modelo de imitación siguiendo a Poggio Bracciolini y otros consideraban tomar lo mejor de cada autor. Además, Erasmo, con una noción de decoro histórico, señaló el problema de considerar a Cicerón como el modelo máximo al no ser un autor cristiano, enfatizando así la identidad del imitador cristiano sobre la insuficiencia de los modelos paganos. Esto dio origen a la reivindicación de la aemulatio, rivalizar con y superar al modelo de Quintiliano como ideal renacentista presente en autores como John Cole, Juan Luis Vives o Philip Sidney. En cualquier caso, una imitación simple de tipo mimético no era suficiente, pues debía quedar clara la aportación nueva al tema, ilustrada por Sumillera con los ejemplos de Du Bellay y Spenser, y el famoso soneto de Les antiquitez de Rome. En la misma línea, ya desde Quintiliano y Horacio, se advertía en contra de las imitaciones serviles. Durante el Renacimiento se suscitaron diversas aproximaciones al asunto en las que participaron Philip Sidney, Thomas Elyot, Thomas Watson, Thomas Haywood, Joseph Hall, Ben Jonson, John Dryden, entre otros. Destaca la de Sidney por su complejidad, pues postula que la imitatio no sólo copia a la naturaleza, sino también al proceso creativo de ésta. Así, Sidney otorga un estatus divino al poeta en su capacidad de creación de mundos que pueden superar a la realidad natural.

En el capítulo cuatro, la autora defiende la tesis de que la inventio se convirtió en uno de los conceptos centrales para discutir y juzgar la poesía renacentista inglesa. En primera instancia, rastrea el uso de "to invent" como un término altamente elogioso y sinónimo tanto para la escritura de ficción como de la poesía. Ya los poetas de la Pléiade consideraban la inventio para evaluar una composición poética. En Inglaterra, la mayor parte de los tratados de la materia discuten el tema desde las últimas décadas del siglo xvi. De hecho, la falta de inventio se interpreta como un acto de repetición estéril; sin embargo, en otros ámbitos fuera de la poética, se veía de manera negativa, siguiendo objeciones de corte platónico y de los primeros puritanos ingleses. 
En el capítulo final, se refuerza la idea de que en el Renacimiento la inventio, vinculada a la facultad imaginativa, es superior a la imitatio para la poesía. Específicamente, la imaginación engendra la inventio, así el poeta se considera un artista imaginativo, cualidad vinculada al concepto griego de $\varphi \alpha \nu \tau \alpha \sigma i ́ \alpha$. Luego, examina el concepto de fantasía desde Platón y Aristóteles, hasta las sospechas de autores como Pico della Mirandolla, Ronsard y Motaigne o las dudas de Huarte de San Juan, a pesar de considerarla parte del proceso del pensamiento racional. En el caso inglés, la principal razón para desacreditar la imaginación es su vínculo con los sentidos corporales y, por tanto, la realidad material, siempre falible y cambiante. En cambio, pocas fueron las voces que defendieron dicha capacidad; sin embargo, la imaginación empezó a ganar terreno sobre la inventio en las definiciones de la poesía.

Las conclusiones del libro enfatizan el papel central de la inventio para el periodo, donde inició el cambio que sentó las bases para la ima- ginación creativa del Romanticismo y cuyas raíces se observan con más claridad ya en el siglo XVII. El libro de Sumillera examina con enorme claridad, precisión y erudición un tema amplio en el que se ligan múltiples aristas: la retórica, la elocuencia, la gramática, la poética y las poéticas tanto de las lenguas clásicas, como de las vernáculas, donde también influyeron la tradición y el pensamiento religioso contemporáneo. Además, el libro destaca por poder vincular el tema de manera diacrónica desde sus orígenes clásicos hasta sus proyecciones en la visión romántica de la poesía. Dicha característica y los rasgos metodológicos, sin duda, posicionan este trabajo en la línea de clásicos de la literatura comparada como Literary Language \& Its Public in Late Latin Antiquity and in the Middle Ages de Auerbach. Así, las múltiples aportaciones de la investigación de Sumillera hacen del libro un texto de enorme utilidad tanto para especialistas en literatura inglesa, como para los interesados en el Renacimiento y la poesía europea, en general.

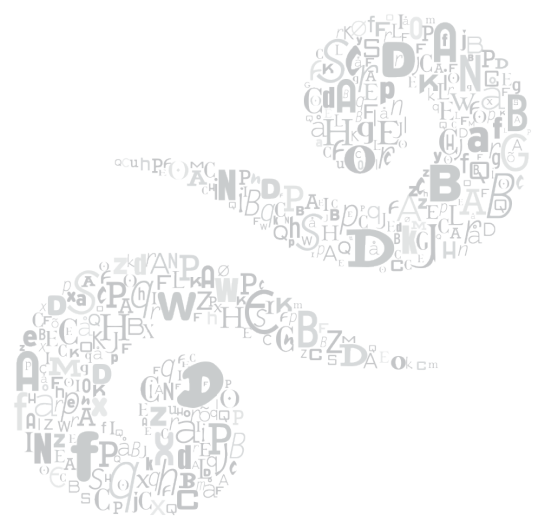

